Casos Clínicos

Arch. Esp. Urol., 61, 6 (723-729), 2008

\section{LYMPHOEPITHELIOMA-LIKE BLADDER CARCINOMA: LITERATURE REVIEW AND CASE REPORT}

\author{
Gonzalo Bueno Serrano, Fernando Arias Fúnez, \\ Raquel González López, Constantino Varona Crespo', \\ Víctor Díez Nicolás, Sara Díaz Naranjo y Ángel \\ Escudero Barrilero.
}

Service of Urology y Service of Pathology'. Ramón y Cajal University Hospital. Madrid. Spain.

Summary.- OBJECTIVE: Lymphoepithelial-carcinoma or lymphoepithelioma-like carcinoma is a rare tumour, the histology of which remembers nasal pharyngeal is lymphoepitheliomas. Their presence has been described in multiple localizations, but only 55 cases have been described in the bladder. We present a new case of bladder lymphoepithelial carcinoma and performed a review of all published cases, with the aim of defining its characteristics and try to obtain a therapeutic and prognostic guide applicable to this disease.
METHODS: We reviewed the literature related to lymphoepithelial carcinoma and epidemiological characteristics, treatments administered, and outcomes of the 56 published cases (including ours) have been analyzed, both globally and as a function of histological subtypes following the classification of Amin et al.

RESULTS: 56 cases have been described, 40 males and 16 women, with a mean age of 69 years. Nineteen of the pure subtype (33.9\%), 20 of the predominant type (35.7\%) and 11 focal (19.6\%) were diagnosed, without any indications of histology in six of them (10.7\%). Regarding tumor stages: $10.7 \%(6)$ were $11,57.1 \%(32) \mathrm{T} 2$, and $30.4 \%(17)$ T3. $58.9 \%$ of the cases underwent transurethral resection (TUR), 35.7\% radical cystectomy, and 5.4\% partial cystectomy. $42.9 \%$ did not receive any adjuvant treatment, $30.4 \%$ received chemotherapy, and $19.6 \%$ radiotherapy. Overall survival was $67.9 \%, 64.3 \%$ disease-free, with a mean and median follow up of 34.5 and 25 months respectively. If we differentiate histological subtypes, $84.3 \%$ of the pure, $100 \%$ of the predominant, and $76.7 \%$ of focal presented infiltration (T2/T3). $78.9 \%$ of the pure, $45 \%$ of the predominant and $45.5 \%$ of the focal underwent TUR. $83 \%$ of the pure receive adjuvant treatment, whereas $60 \%$ of the predominant and $63 \%$ of the focal types did not receive any adjuvant treatment. Disease-free survival for stages T2/T3 was $87.5 \%$ for the pure with a median follow up of 39 months, $75 \%$ for the predominant with a median follow-up of 22 months and 0\% for the focal with a median follow-up of 18 months.

CONCLUSIONS: Currently, no specific therapeutic protocol can be established for patients with bladder lymphoepithelial carcinoma, although taking into consideration the apparent good outcome of the pure and predominant subtypes and the bad outcome of the focal subtype, it seems that TUR may be a good alternative in selected patients with pure our predominant histology, even with infiltrative stages. Oppositely, radical treatment with cystectomy and systemic adjuvant treatment seems to be the best choice for focal subtypes.

Keywords: Lymphoepithelial carcinoma. Lymphoepithelioma-like carcinoma. Bladder carcinoma. Bladder tumor.

Resumen.- OBJETIVO: El carcinoma linfoepitelial o carcinoma linfoepitelioma-like es un raro tumor cuya histología recuerda a los linfoepiteliomas de la nasofaringe. Se ha descrito su presencia en múltiples localizaciones, pero en la vejiga tan sólo se han descrito 55 casos en la literatura. Presentamos un nuevo caso de carcinoma linfoepitelial vesical y hacemos una revisión de todos los publicados anteriormente, con la intención de definir sus características e intentar obtener una pauta terapéutica y pronóstica aplicable a esta patología. 
MÉTODOS: Se ha revisado la literatura relativa al carcinoma linfoepitelial y se han analizado las características epidemiológicas, los tratamientos recibidos y la evolución de los 56 casos publicados (incluido el nuestro), tanto de forma global como en función de los subtipos histológicos, según la clasificación de Amin y cols.

RESULTADOS: Se han descrito 56 casos, 40 en hombres y 16 mujeres, con una media de edad de 69 años. Se diagnosticaron 19 del subtipo puro (33,9\%), 20 del predominante $(35,7 \%)$ y 11 del focal $(19,6 \%)$ sin indicarse la histología en 6 de ellos (10,7\%). En cuanto a los estadíos tumorales, el 10,7\% (6) fueron $T 1$, el $57,1 \%(32)$ fueron T2 y el 30,4\% (17) fueron T3. En el 58,9\% de los casos el tratamiento fue la RTU, en el 35,7\% la cistectomía radical y en el 5,4\% la cistectomía parcial. Un 42,9\% no recibieron tratamiento adyuvante, un $30,4 \%$ recibieron quimioterapia y un $19,6 \%$ radioterapia. La supervivencia global con una media de seguimiento de 34,5 meses, y una mediana de 25 fue de 67,9\%, un 64,3\% libres de enfermedad. Si diferenciamos por subtipos histológicos, el 84,3\% de los puros, el $100 \%$ de los predominantes y el $76,7 \%$ de los focales se presentaron con histologías infiltrantes (T2/T3). Un $78,9 \%$ de los puros, un $45 \%$ de los predominantes y un $45,5 \%$ de los focales fueron tratados con RTU. El $83 \%$ de los puros recibió tratamiento adyuvante, mientras que el $60 \%$ de los predominantes y el $63 \%$ de los focales no recibieron ninguna adyuvancia. La supervivencia libre de enfermedad en los estadios T2/T3 fue de 87,5\% para los puros con una mediana de seguimiento de 39 meses, del $75 \%$ para los predominantes con una mediana de 22 meses y del $0 \%$ para los focales con una mediana de 18 meses.

CONCLUSIONES: En el momento actual no se puede definir un protocolo terapéutico especifico para los pacientes afectos de carcinoma linfoepitelial vesical, aunque teniendo en cuenta la aparente buena evolución de los subtipos puro y predominante y la mala del subtipo focal, parece que la RTU podría ser una buena alternativa en determinados pacientes con histología pura o predominante, incluso en estadíos infiltrantes. En cambio, en el subtipo focal el tratamiento radical con cistectomía y adyuvancia sistémica parece la mejor alternativa.

Palabras clave: Carcinoma linfoepitelial. Carcinoma linfoepitelioma-like. Carcinoma vesical. Tumor de vejiga.

\section{INTRODUCCIÓN}

The term lymphoepithelioma is used in reference to certain undifferentiated or poorly differentiated malignant tumors of an epithelial type that affect the nasopharynx, and are histologically characterized by the presence of an abundant inflammatory infiltrate. Those tumors that are histologically reminiscent of such malignancies are referred to as lymphoepithelioma-like carcinoma (LELC) or lymphoepithelial carcinoma (1). Such histological features have been described in body locations as diverse as the salivary glands (2), uvula, soft palate, thymus gland (3), cervix (4), skin, trachea, lung, stomach and the entire urinary tract - including kidneys (5), ureter (6) and bladder (7).

The first report of such a tumor located in the bladder was published in 1991 by Zukerberg et al. (7), in a series of lymphoma-simulating bladder tumors, and to date no more than 60 cases have been described. We present a new case and review the literature in an attempt to define differences with the other types of bladder tumors, with a view to improving the management approach to such patients.

\section{MATERIAL AND METHOD}

A review of the fundamentally Anglo-Saxon literature was made by means of a Pubmed search, with the selection of all those cases of bladder LELC published to date (7-24). Clinical notes and case series, as well as literature reviews, were considered. Since publication of the first case by Zukerberg et al. in 1991, and including our own case, a total of 56 such lesions have been documented to date.

Taking as reference the review published by Porcaro et al., all the cases found were analyzed in terms of patient sex, age and tumor stage at the time of LELC diagnosis, the local treatment applied, the presence or absence of adjuvant therapy (local as well as systemic), the duration of follow-up, and the clinical condition of the patient at the time of publication. Not all these parameters were addressed in each of the communications, however.

The patients were classified into three groups according to the LELC subtype involved (based on the classification of Amin et al.), and an analysis was made of the characteristics of each subtype from the epidemiological perspective and in terms of tumor stage, the treatment received, and the clinical condition of the patient at the time of publication.

The data obtained were analyzed both globally and separately according to LELC subtype and clinical stage.

The absence of certain data in some of the reports, and the lack of follow-up after the publication date, were the main problems we encountered for analyzing the information collected and for drawing conclusions.

We present the case of a 53-year-old male with an unremarkable history, subjected to control for benign prostate hyperplasia (BPH), who presented urine cytology compatible with urothelial carcinoma following several 
TABLE I.

\begin{tabular}{|c|c|c|c|c|c|c|c|c|c|}
\hline References & Year & Sex & Age & Type & Stage & Treatment & Adjuvancy & Follow-up & Outcome \\
\hline Zukerberg & 1991 & $M$ & 76 & Pu & NR & RTU & RT & NR & NR \\
\hline Young & 1993 & $M$ & 81 & Pu & T3 & $\mathrm{CP}$ & CT & 41 & TD \\
\hline ney & 1993 & $M$ & 52 & Pu & T2 & RTU & CT & 72 & NED \\
\hline Dinney & 1993 & $M$ & 68 & $\mathrm{Pu}$ & $\mathrm{T} 2$ & RTU & $\mathrm{CT}$ & 60 & NED \\
\hline Dinney & 1993 & $M$ & 63 & Pu & T2 & RTU & $\mathrm{CT}$ & 11 & NED \\
\hline Amin & 1994 & $M$ & 52 & $\mathrm{Pu}$ & T2 & RTU & $\mathrm{CT}$ & 72 & NED \\
\hline Amin & 1994 & $\bar{M}$ & 68 & Pu & T2 & RTU & CT & 60 & NED \\
\hline Amin & 1994 & $M$ & 63 & $\mathrm{Pu}$ & $\mathrm{T} 2$ & RTU & $\mathrm{CT}$ & 11 & NED \\
\hline Amin & 1994 & $\mathrm{~F}$ & 71 & $\mathrm{Pr}$ & T2 & RTU & CT & 9 & NED \\
\hline Amin & 1994 & $F$ & 67 & $\mathrm{Pr}$ & T3 & $C P$ & RT & 36 & NED \\
\hline Amin & 1994 & $M$ & 55 & $\mathrm{Pr}$ & T2 & $C R$ & $\mathrm{~N}$ & 10 & NED \\
\hline Amin & 1994 & $M$ & 71 & $\mathrm{Pr}$ & T2 & $C R$ & $\mathrm{~N}$ & 6 & NED \\
\hline Amin & 1994 & $\mathrm{~F}$ & 79 & $\operatorname{Pr}$ & T3 & $C R$ & $\mathrm{~N}$ & 2 & NED \\
\hline Amin & 1994 & $M$ & 78 & Fo & T2 & $C R$ & $\mathrm{CT}$ & 84 & TD \\
\hline Amin & 1994 & $M$ & 66 & Fo & T3 & $C R$ & $N$ & 6 & TD \\
\hline Amin & 1994 & $M$ & 68 & Fo & $\mathrm{T1}$ & $C R$ & $\mathrm{~N}$ & 0 & $\mathrm{D}$ \\
\hline Bianchi & 1996 & $M$ & 72 & $\mathrm{Pu}$ & T3 & $C R$ & $\mathrm{CT}$ & 29 & NED \\
\hline Holgman & 1998 & $\mathrm{~F}$ & 61 & $\mathrm{Pu}$ & $\mathrm{T} 2$ & RTU & RT & 216 & D \\
\hline Holgman & 1998 & $M$ & 78 & $\mathrm{Pu}$ & $\mathrm{T1}$ & RTU & RT & 13 & D \\
\hline Holgman & 1998 & $M$ & 65 & $\mathrm{Pu}$ & T2 & RTU & $\mathrm{N}$ & 24 & NED \\
\hline Holgman & 1998 & $\mathrm{~F}$ & 71 & $\operatorname{Pr}$ & T3 & RTU & RT & 21 & $\mathrm{D}$ \\
\hline Holgman & 1998 & $\mathrm{~F}$ & 69 & $\operatorname{Pr}$ & T3 & $\mathrm{CR}$ & RT & 104 & NED \\
\hline Holgman & 1998 & $\mathrm{~F}$ & 65 & $\operatorname{Pr}$ & T3 & $C P$ & $\mathrm{~N}$ & 76 & NED \\
\hline Holgman & 1998 & $F$ & 84 & Fo & T1 & RTU & $\mathrm{N}$ & 66 & TD \\
\hline Holgman & 1998 & $M$ & 72 & Fo & T3 & $C R$ & RT & 68 & TD \\
\hline Holgman & 1998 & $M$ & 71 & Fo & T3 & RTU & RT & 9 & TD \\
\hline Kruslin & 2000 & $M$ & 70 & NR & T2 & RTU & CT IV & 10 & NED \\
\hline Costantinides & 2001 & $M$ & $\mathrm{~N}$ & Pu & T2 & RTU & $\mathrm{CT}$ & 34 & NED \\
\hline Costantinides & 2001 & $M$ & $\mathrm{~N}$ & $\mathrm{Pu}$ & $\mathrm{T1}$ & RTU & CT IV & 28 & NED \\
\hline Costantinides & 2001 & $M$ & $\mathrm{~N}$ & $\operatorname{Pr}$ & T2 & $\mathrm{CR}$ & $N$ & 32 & NED \\
\hline Lopez-B. & 2001 & $\mathrm{~F}$ & 69 & $\mathrm{Pu}$ & T2 & RTU & $\mathrm{CT}$ & 21 & NED \\
\hline Lopez-B. & 2001 & $M$ & 72 & $\mathrm{Pu}$ & T3 & $C R$ & $\mathrm{~N}$ & 32 & NED \\
\hline Lopez-B. & 2001 & $M$ & 81 & $\mathrm{Pu}$ & T2 & RTU & $\mathrm{CT}$ & 47 & NED \\
\hline Lopez-B. & 2001 & $M$ & 69 & $\operatorname{Pr}$ & T2 & RTU & $\mathrm{N}$ & 22 & NED \\
\hline Lopez-B. & 2001 & $\mathrm{~F}$ & 67 & $\mathrm{Pr}$ & T2 & $\mathrm{CR}$ & $\mathrm{N}$ & 22 & NED \\
\hline Lopez-B. & 2001 & $M$ & 73 & $\operatorname{Pr}$ & T3 & CR & $\mathrm{N}$ & 37 & NED \\
\hline Lopez-B. & 2001 & $M$ & 82 & $\operatorname{Pr}$ & T2 & RTU & $\mathrm{N}$ & 49 & NED \\
\hline Lopez-B. & 2001 & $M$ & 74 & $\operatorname{Pr}$ & T2 & RTU & $\mathrm{N}$ & 25 & AWM \\
\hline Lopez-B. & 2001 & $\mathrm{~F}$ & 81 & $\mathrm{Pr}$ & T2 & RTU & $\mathrm{N}$ & 44 & TD \\
\hline Lopez-B. & 2001 & $M$ & 78 & Fo & T2 & RTU & $\mathrm{N}$ & 3 & TD \\
\hline Lopez-B. & 2001 & $\mathrm{~F}$ & 58 & Fo & $\mathrm{T} 2$ & $C R$ & $\mathrm{~N}$ & 19 & TD \\
\hline Lopez-B. & 2001 & $M$ & 71 & Fo & T2 & RTU & $\mathrm{N}$ & 30 & TD \\
\hline Lopez-B. & 2001 & $\mathrm{~F}$ & 69 & Fo & T3 & $C R$ & $\mathrm{~N}$ & 18 & TD \\
\hline Porcaro & 2002 & $M$ & 72 & $\operatorname{Pr}$ & T2 & RTU & $\bar{N}$ & 17 & NED \\
\hline Gastaud & 2002 & $M$ & 58 & NR & T2 & CR & $\mathrm{N}$ & 12 & NED \\
\hline Wrad & 2002 & $M$ & 61 & NR & $\mathrm{Tl}$ & RTU & $\mathrm{N}$ & NR & NR \\
\hline Chen & 2003 & $M$ & 63 & NR & T2 & RTU & $\mathrm{CT}+\mathrm{BCG}$ & 10 & NED \\
\hline Chen & 2003 & $M$ & 73 & NR & T3 & $C R$ & $\mathrm{CT}$ & 26 & NED \\
\hline Dundr & 2003 & $\mathrm{~F}$ & 54 & $\mathrm{Pr}$ & T3 & $C R$ & CT & 16 & AWM \\
\hline Izquierdo-García & 2004 & $M$ & 77 & Pu & T2 & RTU & RT & 39 & NED \\
\hline Izquierdo-García & 2004 & $\mathrm{~F}$ & 82 & $\operatorname{Pr}$ & T2 & RTU & RT & 36 & NED \\
\hline Izquierdo-García & 2004 & $M$ & 74 & Fo & $\mathrm{T1}$ & RTU & RT & 54 & NED \\
\hline Yaqoob & 2005 & $\mathrm{~F}$ & 55 & $\mathrm{Pr}$ & T2 & RTU & NR & NR & NR \\
\hline Abascal & 2005 & $M$ & 54 & $\mathrm{Pu}$ & T3 & $C R$ & $\mathrm{CT}$ & 20 & NED \\
\hline Guresci & 2005 & $M$ & 90 & NR & T3 & RTU & $\mathrm{N}$ & 11 & NED \\
\hline Arias and Bueno & 2006 & $M$ & 53 & $\mathrm{Pr}$ & T2 & $C R$ & $\mathrm{CT}$ & 6 & NED \\
\hline
\end{tabular}

M: Male. F: Female. NR: Not reported. Pu: Pure. Pr: Predominant. Fo: Focal. TUR: Transurethral resection. RC: Radical cystectomy. PC: Partial cystectomy. N: None. CT: Chemotherapy. RT: Radiotherapy. CT N: Intravesical chemotherapy. TD: Tumor death. NED: No evidence of disease. D: Death. AWM: Alive with metastasis 
episodes of sparsely symptomatic and self-limiting hematuria. A bladder tumor was diagnosed by ultrasound, and the intravenous urography (IVU) findings proved normal. Transurethral resection (TUR) was targeted to a single 2-cm papillary lesion in the bladder fundus, without incidents. The histological report indicated poorly differentiated carcinoma with a syncytial appearance in the epithelial component and a marked lymphoplas- macytic reaction with transition to high-grade urothelial carcinoma, with infiltration of the muscle layer.

Following thoracic-abdominal-pelvic CAT and bone gammagraphic assessment of disease spread, with no evidence of metastases, a radical cystoprostectomy was decided with ilioinguinal lymphadenectomy and orthotopic bladder resconstruction according to the Studder te-

\section{TABLE II. ANALYZES THE CASES ACCORDING TO THE HISTOLOGICAL TYPE OF TUMOR INOT SPECIFIED IN 6 PUBLICATIONS), BASED ON THE CLASSIFICATION OF AMIN ET AL. (9).}

\begin{tabular}{|c|c|c|c|c|c|}
\hline & Pure & Predominant & Focal & Not stated & Total \\
\hline Number of patients & 19 (33.9\%) & $20(35.7 \%)$ & $11(19.6 \%)$ & $6(10.7 \%)$ & 56 \\
\hline Male & 17 & 9 & 8 & 6 & 40 \\
\hline Female & 2 & 11 & 3 & 0 & 16 \\
\hline Age & & & & 3 & \\
\hline Mean & 67.7 (of 17) & 68.9 (of 19) & 71.7 (of 11) & 69.1 (of 6) & 69.1 (of 53) \\
\hline Range & $52-81$ & $53-82$ & $58-84$ & $58-90$ & $52-90$ \\
\hline \multicolumn{6}{|l|}{ Stage } \\
\hline $\mathrm{T} 1$ & 2 & 0 & 3 & 1 & 6 \\
\hline $\mathrm{T} 2$ & 13 & 13 & 4 & 3 & 33 \\
\hline T3 & 4 & 7 & 4 & 2 & 17 \\
\hline \multicolumn{6}{|l|}{ Treatment } \\
\hline TUR & 15 & 9 & 4 & 5 & 33 \\
\hline CTX P & 1 & 2 & 0 & 0 & 3 \\
\hline CTX T & 3 & 9 & 7 & 1 & 20 \\
\hline Adjuvant therapy & & & & 1 & \\
\hline $\mathrm{N}$ & 2 & 13 & 7 & 2 & 24 \\
\hline RT & 4 & 4 & 3 & 0 & 11 \\
\hline CT IV & 1 & 0 & 0 & 1 & 2 \\
\hline Systemic CT & 12 & 3 & 1 & 2 & 18 \\
\hline \multicolumn{6}{|l|}{ Follow-up (months) } \\
\hline Mean & 46.1 (of 18) & 30.15 (of 19) & 32.4 (of 11) & 13.8 (of 5) & 34.5 \\
\hline Median & 35.5 & 22 & 19 & & 30.37 \\
\hline Range & $11-216$ & $2-104$ & $3-84$ & & \\
\hline \multicolumn{6}{|l|}{ Outcome } \\
\hline NED & 15 & 15 & 1 & 5 & 36 \\
\hline AWM & 0 & 2 & 0 & 0 & 2 \\
\hline TD & 1 & 1 & 9 & 0 & 11 \\
\hline D & 2 & 1 & 1 & 0 & 4 \\
\hline NR & 1 & 1 & 0 & 1 & 3 \\
\hline
\end{tabular}


chnique. The patient course is good, and the definitive histological diagnosis corresponded to cytological highgrade urothelial carcinoma with a lymphoepithelial pattern and infiltration of the muscle layer, though without spreading beyond the latter. Specifically, the tumor was defined as dominant subtype lymphoepithelial urothelial carcinoma, stage pT2G3NO. Adjuvant chemotherapy was provided despite the absence of metastases in the imaging studies, in the form of 4 cycles of cisplatin 170 $\mathrm{mg} / \mathrm{m} 2)$ and gemcytabine $(100 \mathrm{mg} / \mathrm{m} 2)$. One year after diagnosis, the patient remains free of symptoms and shows no tumor relapse.

\section{RESULTS}

Table 1 shows the total 56 cases of LELC published between 1991 and 2006, with the most relevant data collected from the different literature sources. Three important series are found, corresponding to López-Beltran, Amin and Holgman. The rest of publications correspond to isolated cases or small patient series.

The total series of 56 patients comprised 40 males $(71.4 \%)$ and 16 females $(28.6 \%)$ with a mean age at the time of diagnosis of 69.17 years $(69.3$ years in males and 68.8 in females)(range 52-90). Based on the classification of Amin et al., 19 corresponded to the pure subtype $(33.9 \%), 20$ to the predominant $(35.7 \%)$ and 11 to the focal subtypes $(19.6 \%)$, while the histological subtype was not indicated in 6 cases $(10.7 \%)$. While not specified in many cases land therefore not reflected in the tables), in the predominant and focal presentations the other most commonly associated histological subtypes were high-grade urothelial tumors, followed by low-grade malignancies, adenocarcinoma and squamous cell carcinoma. Regarding tumor stage, the most frequent presentation corresponded to $\mathrm{T} 2$, with $57.1 \%$ of the cases (32 patients), followed by T3 with $30.4 \%$ (17 patients), and $\mathrm{T} 1$ with $10.7 \%$ (6 patients).

In 33 patients $(58.9 \%)$, treatment consisted of transurethral resection (TUR), with radical cystectomy in 35.7\% of cases (20 patients), and partial cystectomy in $5.4 \%$ ( 3 patients). No adjuvant treatment was provided in $42.9 \%$ (24 patients), while $30.4 \%$ received systemic chemotherapy $(C T)(17$ patients), $3.6 \%$ received intravesical $\mathrm{CT}(2$ patients), $1.8 \%$ received systemic CT plus bacille Calmette-Guerin (BCG)(one patient), and $19.6 \%$ received radiotherapy (11 patients).

Although the figure varied greatly among the different literature sources, the mean duration of follow-up was 35.4 months (median 25 months; range 0-216). At the time of the different publications, 38 patients $(67.9 \%)$ were still alive, and of these $36(64.3 \%)$ were free of disease. Of the 15 deaths $(26.8 \%)$, four were due to causes other than the tumor disease.

In relation to the histological subtypes, and although in 6 cases the subtype was not specified, we found the pure and predominant forms to be the most frequent presentations (69.6\%) both globally and by sexes. The pure subtype was more common in males $(42.5 \%)$, and the predominant subtype in females $(68.8 \%)$.

The more abundant the lymphoepithelial component, the earlier the patient age at tumor onset: 67.7 years on average for the pure form, 68.9 for the predominant subtype, and 71.7 for the focal presentation.

Regarding tumor stage, $84.3 \%$ of the pure, $100 \%$ of the predominant, and $76.7 \%$ of the focal subtypes initially manifested as infiltrating lesions (stages T2 and T3).

On considering treatment according to the tumor subtype involved, TUR was the most frequent option - being applied in $78.9 \%$ of the pure, $45 \%$ of the predominant, and $45.5 \%$ of the focal subtypes. Radical cystectomy was performed in $15.8 \%$ of the pure, $45 \%$ of the predominant, and $54 \%$ of the focal subtypes. Regarding adjuvant therapy, $62 \%$ of the pure subtypes received systemic chemotherapy, and $21 \%$ received radiotherapy, while $60 \%$ of the predominant and $63 \%$ of the focal presentations received no adjuvant treatment.

Disease-free survival in stages T2 and T3 was $87.5 \%$ for the pure subtype, with a median follow-up of 39 months; $75 \%$ for the predominant form, with a median follow-up of 22 months; and $0 \%$ for the focal subtypes, with a median follow-up of 18 months.

\section{DISCUSSION}

Approximately $90 \%$ of all bladder tumors are of urothelial-transitional origin - the remaining 10\% corresponding to sarcomas and infrequent tumors, including lymphoepithelial carcinoma or lymphoepithelioma-like carcinoma (18). The incidence of tumors of this kind is $0.4-1.3 \%$ of all bladder tumors $(12,17,20,21)$, though in a relevant number of cases such lesions are reported as poorly differentiated urothelial tumors in the context of a great inflammatory component. These malignancies are mainly observed in patients over 60 year of age, with a mean of 69 years - though the figure varies slightly according to the histological subtype involved. Males are affected in $70 \%$ of cases. These percentages are similar to those reported for urothelial carcinoma.

The most common presenting symptom is hematuria, generally accompanied by urgency and frequent micturition. There are no gross diagnostic variations allowing us to differentiate lymphoepithelial carcinoma or lymphoepithelioma-like carcinoma from the other types of bladder tumors at either macroscopic level or in terms of lesion location, since the tumor can present as a single or as multiple lesions measuring from $0.9-5 \mathrm{~cm}$ in size, and located anywhere in the bladder (7-24). Only the histopathological study is able to differentiate such malignancies from the rest. 
In histological terms, these tumors are composed of epithelial cells with a sheet-like distribution and syncytial appearance, with a vesicular nucleus, prominent nucleolus, and an intense lymphoid reaction $(1,7,9)$. Necrotic foci may be present. The tumor cells can infiltrate the lamina propria, the muscularis propria, or even the perivesical fatty tissue. As has been commented, these lesions can be associated to any other type of bladder tumor, and in all tumor stages.

Immunohistochemical techniques are required to demonstrate both the epithelial component (based on antigens such as EMA, CD46v6 and cytokeratins such as AE I/ $A E 3, C K 7$ and $C K 20$ ), and the lymphocytic component (CD2 1, CD20, Cd79a, CD45RO, CD68 and D33). The lymphoid population found is a combination of $T$ and $B$ cells, with a predominance of the former (21).

Amin et al., classified LELC into three subgroups according to the percentage represented by the fumor with respect to the total tumor tissue. Thus, pure $(100 \%)$, predominant $(>50 \%)$ and focal subtypes $(<50 \%)$ were defined, and the latter two forms may be present in association with any other type of bladder tumor.

Regarding the differential diagnosis, consideration is required of poorly differentiated transitional cell tumors with an important inflammatory component; primary bladder lymphomas which while rare, entail a different diagnostic and therapeutic approach; chronic cystopathy, where the inflammatory component in some cases is so intense that any scarce tumor cell presence could go undetected; and small-cell tumors (negative for CK2O and $\operatorname{CD} 46 v 6)(9,13,17,20,23)$. Some authors suggest the advisability of discarding a primary nasopharyngeal tumor before diagnosing a primary bladder tumor (21), due to the possibility that the latter may actually constitute metastasis of the former.

Although metastases are not frequent, they have been described locally within the regional lymph nodes, and also at a distance in the liver, kidneys or retroperitoneum (7-24).

Studies have been made of the possible relationship between this type of tumor and Epstein-Barr virus (EBV) infection. However, while in other locations (e.g., nasopharynx or lung) such an association has been confirmed, the possibility has not been demonstrated in the bladder $(8,25,26)$.

The existing data suggest that these tumors most often manifest in stages T2 and T3. However, it cannot be ruled out that this may be the result of bias during diagnosis, since in those cases where the lesions present in stage $T 1$, the scant sample collected during TUR may be insufficient to distinguish the lesion from a tumor with abundant inflammatory infiltration. As a result, in the absence of muscle infiltration, a cystectomy would not be performed, and the harvested tissue would be insufficient to establish a firm histological diagnosis.
Regarding local treatment of the disease, most authors resort to TUR $(58.9 \%)$, despite the fact that in $78.8 \%$ of the cases the histology shows an infiltrating tumor. Nevertheless, and likewise because $91.1 \%$ of the cases present with histologically manifest infiltration, many authors prefer a cystectomy (mainly radical) as treatment. In relation to adjuvant therapy, no consensus has been reached, since only $57.1 \%$ of the cases studied received systemic treatment, despite the large number of infiltrating lesions. Even a large proportion of T3 tumors received no chemotherapy (only $62.5 \%$ ); of these cases, one-half received radiotherapy without systemic chemotherapy. In the literature, most of the pure tumors were subjected to TUR independently of the tumor stage, and these were the lesions that predominantly received adjuvant therapy.

As to patient survival, this type of tumor appears to offer greater survival than the rest of histologial subtypes of bladder tumor, even in the infiltrating stages of the disease.

With over 30 months of follow-up on average (median 25 months), the pure and predominant subtypes showed a disease free survival of over $75 \%$, with a percentage of infiltrating tumors of $89 \%$ and $100 \%$, respectively. The reason for this potential longer survival is not clear.

Some authors explain such survival in terms of an increased efficacy of the host immune response (reflected by the important lymphocytic component) to the tumor in these patients (9). Other investigators point out the increased presence of symptoms, allowing an earlier diagnosis when the tumor is still small and tractable (17), or even to the increased sensitivity of these fumors to chemo- and radiotherapy (7-24).

However, while taking these possibilities into account, the fact that other more aggressive subtypes are absent or are present in only a small percentage of the total tumor may also play an important role, regardless of the behavior of LELC isolatedly - since the focal subtype (where the percentage of other associated tumors is greater) exhibits far higher mortality than the other subtypes despite more aggressive treastment in the form of radical cystectomy.

It would be advisable to investigate whether the increased survival of the pure subtype is related to the intrinsic histology of the fumor or to the fact that it has been the lesion subtype most often subjected to adjuvant therapy.

\section{CONCLUSION}

While lymphoepithelial carcinoma or lymphoepithelioma-like carcinoma is a rare type of bladder tumor without clinical or diagnostic characteristics distinguishing it from the rest of bladder tumors, it must be taken into consideration on establishing the histopathological 
diagnosis. Although these tumors usually manifest in stages $\mathrm{T} 2$ and $\mathrm{T} 3$, the pure and predominant subtypes appear to offer greater patient survival than other types of bladder tumors, and in some cases even TUR may constitute a good management option - though the cause underlying this apparently more favorable course of the disease remains to be clarified. The focal subtype of the disease does not appear to offer such favorable survival, however. In this case radical cystectomy appears to remain the most effective treatment option in the infiltrating stages of the tumor.

No conclusive data can be drawn from the present review regarding the advantages of adjuvant therapy (both chemo- and radiotherapy) in the local management of these malignancies. Although the improved survival of the pure and predominant subtypes appears to be related to their histological characteristics, these are also the subtypes most often subjected to adjuvant therapy. It therefore should be examined whether this fact influences such improved survival, and if this were the case, then studies should be made to define the best treatment regimen. Given the aggressivity of the focal subtype, it would seem reasonable to assume that systemic therapy would be useful - though there are still no data to confirm this possibility.

It should be stressed that the difficult histopathological diagnosis of such tumors may cause some of them to go undetected in daily practice. The means necessary for correct diagnosis must be applied, with a view to confirm whether the presence of LELC offers a better prognosis or may even modify treatment, based on the information gained from a larger number of cases.

\section{REFERENCES AND RECOMENDED READINGS (*of special interest, ${ }^{* *}$ of outstanding interest)}

1. ZUKERBERG, L.R.; HARRIS, N.L.; YOUNG, R.H.: "Carcinomas of urinary bladder simulating malignant lymphoma”. Am. J. Surg. Pathol., 15: 569, 1991.

2. ABASCAL JUNQUERA, J.M.; MARTOS CALVO, R.; SALVADOR LACAMBRA, C. y cols.: "Primary lymphoepithelioma-like carcinoma urinary bladder". Actas Urol. Esp., 29: 419, 2005.
*3. AMIN, M.B.; RO, J.Y.; LEE, K.M. y cols.: "Lymphoepithelioma-like carcinoma of the urinary bladder". Am. J. Surg. Pathol., 18: 466, 1994.

4. BIANCHI, E.; LISATO, L.; RIMONDI, A.P. y cols.: "Lympho-epiteliona-like carcinoma of the urinary bladder". J. Urol. Path., 5: 45, 1996.

5. CHEN, K.C.; YEH, S.D.; FANG, C.L. y cols.: "Lymphoepithelioma-like carcinoma of the urinary bladder". J. Formos. Med. Assoc., 102: 722, 2003.

6. CONSTANTINIDES, C.; GIANNOPOULOS, A.; KYRIAKOU, G. y cols.: "Lymphoepithelioma-like carcinoma of the bladder". BJU Int., 87: 121, 2001.

7. DINNEY, C.P.N.; RO, J.Y.; BABAIAN, R.J. y cols.: "Lympho-epitelioma of the bladder: A clinicopathological study of 3 cases". J. Urol., 149: 840, 1993.

8. DUNDR, P.; PESL, M.; POVYSIL, C. y cols.: "Large cell neuroendocrine carcinoma of the urinary bladder with lymphoepithelioma-like features". Pathol. Res. Pract., 199: 559, 2003.

9. GASTAUD, O.; DEMAILLY, M.; GUILBERT, E. y cols.: "Lymho-epitelioma of the bladder. Discussion of pathogenesis". Prog. Urol., 12: 318, 2002.

10. GURESCI, S.; DOGANAY, L.; ALTANER, S. y cols.: "Lymphoepithelioma-like carcinoma of the urinary bladder: A case report and discussion of differential diagnosis". Int. Urol. Nephrol., 37: 65, 2005.

11. HOLMANG, S.; BORGHEDE, G.; JOHANSSON, S.L.: "Bladder carcinoma with lymphoepithelioma-like differentiation: A report of 9 cases". J. Urol., 159: 779, 1998.

12. IZQUIERDO-GARCIA，F.M.; GARCIA-DIEZ, F.; FERNANDEZ, I. y cols.: "Lymphoepithelioma-like carcinoma of the bladder: Three cases with clinicopathological and p53 protein expression study". Virchows Arch., 444: 420, 2004.

13. KRUSLIN, B.; STANIC, G.; BELICZA, M. y cols.: "Carcinoma of the urinary bladder resembling lymphoepithelioma". Lijec Vjesn., 122: 270, 2000.

14. LOPEZ-BELTRAN, A.; LUQUE, R.J.; VICIOSO, L. y cols.: "Lymphoepithelioma-like carcinoma of the urinary bladder: A clinicopathologic study of 13 cases". Virchows Arch., 438: 552, 2001.

15. PORCARO, A.B.; GILIOLI, E.; MIGLIORINI, F. y cols.: "Primary lymphoepithelioma-like carcinoma of the urinary bladder: Report of one case with review and update of the literature after a pooled analysis of 43 patients". Int. Urol. Nephrol., 35: 99, 2003.

16. YAQOOB, N.; KAYANI, N.; PIRYANI, J. y cols.: "Lymphoepithelioma-like carcinoma of urinary bladder: (LELCA)”. J. Pak. Med. Assoc., 55: 402, 2005.

17. YOUNG, R.H.; EBLE, J.N.: "Unusual forms of carcinoma of the urinary bladder". Hum. Pathol., 22: 948, 1991.

18. WARD, J.N.; DONG, W.F.; PITTS, W.R. Jr.: "Lymphoepithelioma-like carcinoma of the bladder". J. Urol., 167: 2523, 2002. 